\title{
Follicular Bronchiolitis Mimicking Lung Cancer in a Patient with Primary Sjögren's Syndrome
}

\author{
Seunghwan Shin ${ }^{1}$, You-Jung $\mathrm{Ha}^{1,4}$, Eun Ha Kang ${ }^{1,4}$, Yeong Wook Song ${ }^{2,3,4}$, Yun Jong Lee ${ }^{1,4}$ \\ ${ }^{1}$ Division of Rheumatology, Department of Internal Medicine, Seoul National University Bundang Hospital, Seongnam, ${ }^{2}$ Department of Internal \\ Medicine, Seoul National University Hospital, Seoul, ${ }^{3}$ WCU Department of Molecular Medicine and Biopharmaceutical Sciences, Medical \\ Research Institute, Seoul National University College of Medicine, Seoul, ${ }^{4}$ Department of Internal Medicine, Seoul National University College of \\ Medicine, Seoul, Korea
}

Follicular bronchiolitis (FB) is an uncommon pulmonary lymphoproliferative disorder that is characterized by the presence of peribronchiolar hyperplastic lymphoid follicles with reactive germinal centers. FB could be associated with systemic illnesses including immunodeficiency, infection, and autoimmune diseases. In Korea, a single case of FB with rheumatoid arthritis was recently described but there has been no report on FB associated with other rheumatic diseases. Herein, we describe the first case of FB presenting nodular ground-glass opacities (GGO), which mimicked lung cancer, in patients with primary Sjögren's syndrome (SS). The differential diagnosis of nodular GGO lesions should include FB although it is a rare manifestation in SS patients. (J Rheum Dis 2019;26:206-210)

Key Words. Sjögren's syndrome, Lung neoplasms, Lung diseases, interstitial, Bronchiolitis

\section{INTRODUCTION}

Sjögren's syndrome (SS) is a systemic autoimmune disease characterized by the lymphocytic infiltration of the exocrine glands which often results in dryness of the mouth and eyes. Systemic manifestations occur in $30 \%$ to $40 \%$ of patients with SS [1]. SS can affect the lungs in $10 \%$ to $20 \%$ of the patients and its pulmonary involvement includes airway abnormalities, interstitial lung disease (ILD), and lymphoproliferative disorders [2].

Follicular bronchiolitis (FB) is a rare small airway disease, and it is pathologically characterized by the presence of hyperplastic lymphoid follicles with germinal centers in the walls of small airways [3]. Radiographically, the most common findings of FB are bilateral centrilobular small nodules that are 1 to $3-\mathrm{mm}$ in diameter and are often associated with bilateral patch ground-glass opacities (GGO) on chest computed tomography (CT) scans [4]. FB may occur without associated diseases (idiopathic) or as a secondary form associated with other diseases including autoimmune disorders such as rheumatoid arthritis (RA). In addition, FB has been considered a pulmonary manifestation of SS since 1985 after Fortoul et al. [5] reported pathologically proven FB in three patients with SS.

In 1993, Lee et al. [6] reported the first Korean case of idiopathic FB and a single case of FB secondary to RA was recently published in 2016 [7]. However, there has been no FB case associated with SS in Korea until now. Herein, we describe a specific case of FB, presenting a newly developed nodular GGO in a SS patient with ILD, and provide the literature review of Korean FB cases.

\section{CASE REPORT}

A 67-year-old non-smoking female patient had been diagnosed as having primary SS with ILD for seven years, based on her having dry mouth, recurrent parotid gland

Received : November 30, 2018, Revised : December 31, 2018, Accepted : January 22, 2019

Corresponding to : Yun Jong Lee (D) http://orcid.org/0000-0001-7615-8611

Division of Rheumatology, Department of Internal Medicine, Seoul National University Bundang Hospital, 82 Gumi-ro 173beon-gil, Bundang-gu, Seongnam 13620, Korea. E-mail : yn35@snu.ac.kr

Copyright (c) 2019 by The Korean College of Rheumatology. All rights reserved.

This is an Open Access article, which permits unrestricted non-commerical use, distribution, and reproduction in any medium, provided the original work is properly cited. 
swelling, hyposalivation, positive anti-Ro/SSA, and focal sialadenitis. Thirty-one months ago, chest high resolution CT (HRCT) scans showed mild diffuse reticular opacities and traction bronchiectasis in the peripheral lower lobe of both lungs and a nodular GGO in the anterior segment of the left upper lobe (LUL). She visited our Rheumatology clinic 24 months ago and was treated with mizoribine, artificial saliva, and tears. The patient had an uneventful course during the follow-up, and her serial pulmonary function tests (PFTs) were normal over the recent 24 months. Seven months prior to admission, in the follow-up chest HRCT scan, the longitudinal diameter of the nodular GGO lesion had slightly increased (from 13.5 to $15.0 \mathrm{~mm}$ over 24 months), and the possibility of mini- mally invasive adenocarcinoma could not be excluded (Figure 1). Six month later, another chest HRCT showed a newly developed GGO nodule (the diameter of $11 \mathrm{~mm}$ ) in the superior segment of the right lower lobe (RLL; Figure 2), but, the LUL nodular lesion was not changed. Under the suspicion of lung cancer, further work-up was performed. Her complete blood count, renal, and liver function tests were within normal limits and C-reactive protein and complement levels were also normal. The erythrocyte sedimentation rate was $64 \mathrm{~mm} / \mathrm{h}$, and there was no evidence of monoclonal gammopathy. Serum tumor markers such as neuron-specific enolase, cytokeratin-19 fragments, carcinoembryonic antigen, and squamous cell carcinoma antigen were within normal ranges.
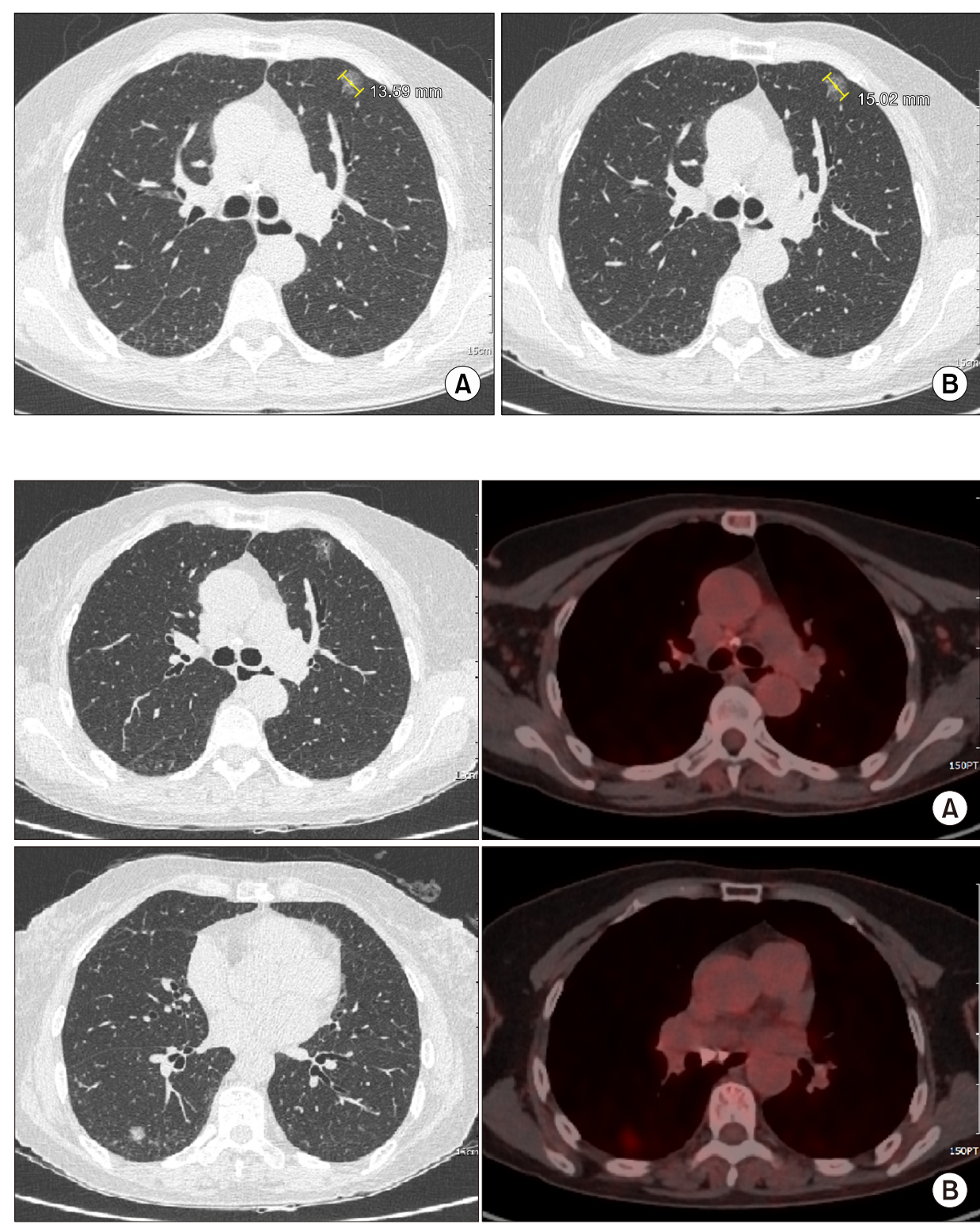

Figure 2. Chest computed tomography (CT) and positron emission tomography (PET)-CT images. (A) Matched CT and $\mathrm{PET} / \mathrm{CT}$ scan slices demonstrated a $15 \mathrm{~mm}$-sized lesion of nodular ground-glass opacities (GGO) without pathological uptake of ${ }^{18} \mathrm{~F}$-fluorodeoxyglucose in the anterior segment of the left upper lobe. (B) Chest CT scan images revealed a new GGO nodule in the superior segment of the right lower lobe and the corresponding PET-CT slice showed the lesion with hypermetabolism (maximal standardized uptake value 2.1). 
There were no malignant cells in the bronchoscopy and endobronchial transbronchial needle aspiration. Wholebody positron emission tomography/CT demonstrated a mild hypermetabolic focus corresponding to the RLL lesion, but no uptake of ${ }^{18} \mathrm{~F}$-fluorodeoxyglucose in the LUL lesion (Figure 2). The brain magnetic resonance imaging revealed no evidence of metastasis. Under the impression of adenocarcinoma in situ, she underwent superior segmentectomy of the RLL with selective mediastinal lymph node dissection. However, pathological examination revealed peri-bronchiolar lymphoid hyperplasia, showing polymorphous lymphocytes and intact lung parenchymal architecture. Additionally, immunohistochemistry showed B cell dominant infiltration with some reactive follicles (Figure 3), and the assay for IgH gene rearrangement demonstrated a polyclonal pattern. Finally, she was diagnosed as having FB associated with SS, but she was advised for regular radiographic follow ups for the LUL lesions. Four months after the segmentectomy, the chest HRCT showed no new findings and that the size of the LUL lesion was stable.

\section{DISCUSSION}

Apart from this recent case, a literature search revealed only five Korean FB cases. Three of the cases were idio- pathic, while the others were secondary to multicentric Castleman's disease or RA [6-10]. Table 1 presents a summarized comparison of clinical features in our and the previously reported Korean cases of FB. They include four adult cases (male to female 2:2, the range of age from 37 to 56 years) and a single pediatric case. Most of the previous cases had respiratory symptoms such as productive cough and dyspnea. However, the current case did not have any respiratory symptoms. Interestingly, among the four Korean adult FB cases, two patients underwent a surgical approach under the suspicion of lung malignancy similar to the current case.

Patients with connective tissue diseases, especially RA, systemic sclerosis, and inflammatory myopathies are known to have increased risk of lung cancer [11]. In patients with SS, the incidence of lymphoma is much higher than the general population [1]. Moreover, a nationwide population-based study of Korean SS patients recently described that the most common cause of death was respiratory disease and lung cancer had the highest incidence among death-related cancers [12]. The present case was followed up with a chest $\mathrm{CT}$ because she had shown a pulmonary nodule suspicious of minimally invasive adenocarcinoma in the LUL. During follow-up, the size of the LUL nodule was slightly increased and a newly developed hypermetabolic lesion was noted in the RLL.
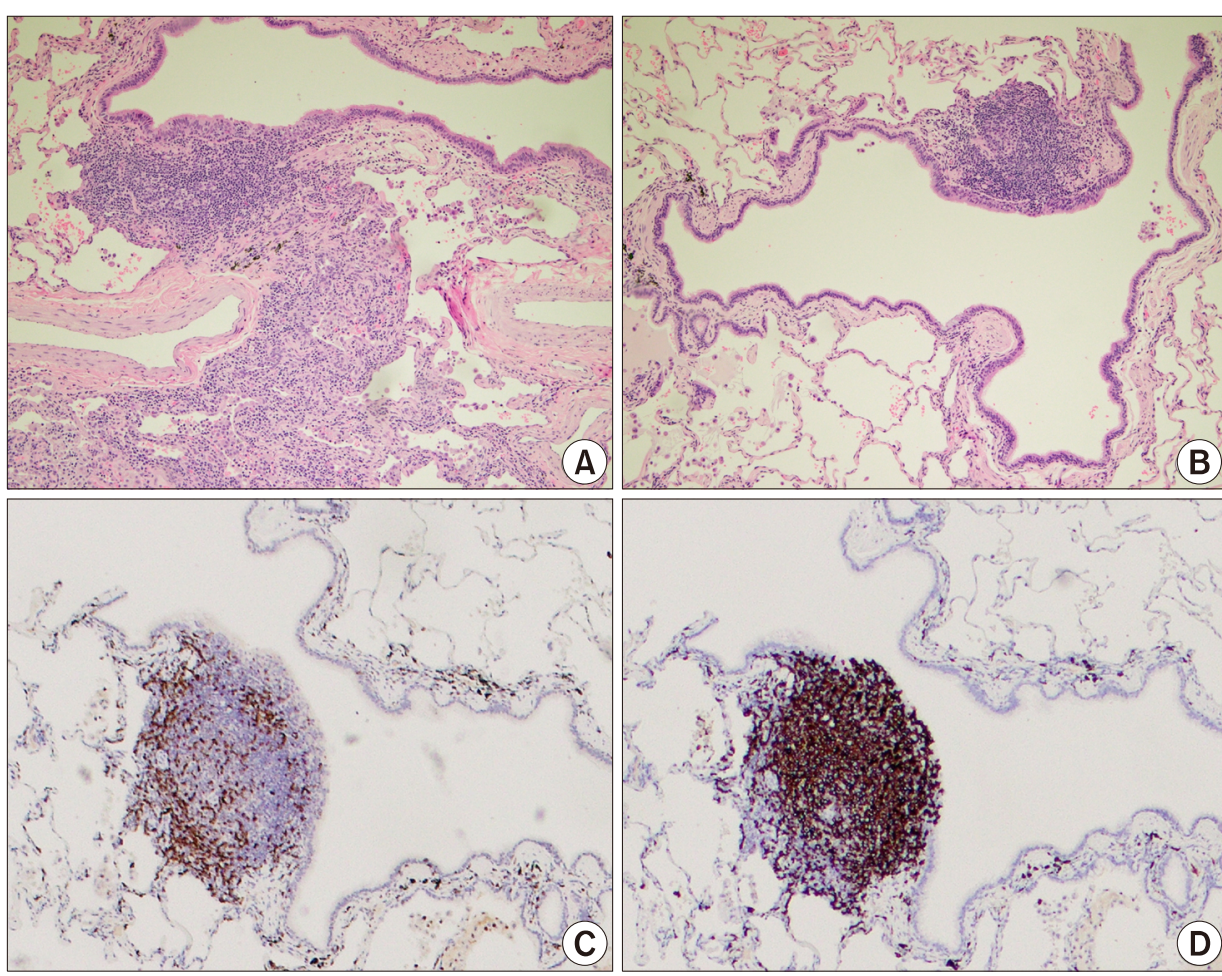

Figure 3. Pathology of lung biopsy specimen. In hematoxylin and eosin stained section, peribronchiolar lymphoid hyperplasia with polymorphous lymphoid populations was observed $(A, \times 100)$. Additionally, the destruction of peribronchial alveolar septa was not shown $(B, \times 100)$. Immunohistochemistry study for CD3 (C) and CD20 (D) showed that most mononuclear cells were nonmalignant $B$ cells in the peribronchial follicular lymphoid hyperplasia $(\times 40)$. 
Table 1. Comparison of clinical features of Korean patients with follicular bronchiolitis

\begin{tabular}{|c|c|c|c|c|c|c|}
\hline & Lee et al. [6] & Kim et al. [9] & Hwangbo et al. [8] & Lee et al. [7] & Jeong et al. [10] & Current case \\
\hline $\begin{array}{l}\text { Age (yr)/ } \\
\text { Gender }\end{array}$ & 46/male & 49/female & 37/female & 56/male & 12/male & $67 /$ female \\
\hline $\begin{array}{r}\text { Respiratory } \\
\text { symptoms }\end{array}$ & $\begin{array}{l}\text { Dyspnea, } \\
\text { cough, sputum }\end{array}$ & Cough, sputum & $\begin{array}{l}\text { Cough, sputum, } \\
\text { weight loss }\end{array}$ & Dyspnea & None & None \\
\hline $\begin{array}{l}\text { Underlying } \\
\text { disease }\end{array}$ & None & None & $\begin{array}{l}\text { Multicentric } \\
\text { Castleman's } \\
\text { disease }\end{array}$ & $\begin{array}{l}\text { Rheumatoid } \\
\text { arthritis }\end{array}$ & None & $\begin{array}{l}\text { Sjögren's } \\
\text { syndrome }\end{array}$ \\
\hline $\begin{array}{l}\text { Chest CT/ } \\
\text { X-ray }\end{array}$ & $\begin{array}{l}\text { Interstitial } \\
\text { infiltration in } \\
\text { the peripheral } \\
\text { portion of both } \\
\text { lower lung field }\end{array}$ & $\begin{array}{l}5 \times 4 \mathrm{~cm} \\
\text { sized lobular, } \\
\text { ill-defined } \\
\text { marginal mass } \\
\text { with internal } \\
\text { calcification in } \\
\text { the right upper } \\
\text { lobe }\end{array}$ & $\begin{array}{l}\text { Thickening of } \\
\text { bronchovascular } \\
\text { bundles, } \\
\text { interlobular } \\
\text { septal thickening, } \\
\text { poorly defined } \\
\text { centrilobular } \\
\text { nodules in both } \\
\text { lungs }\end{array}$ & $\begin{array}{l}\text { linear and } \\
\text { reticular densities } \\
\text { and small patchy } \\
\text { areas of GGOs } \\
\text { in the subpleural } \\
\text { area of both lungs }\end{array}$ & $\begin{array}{l}\text { Migrating } \\
\text { ill-defined, } \\
\text { irregularly } \\
\text { shaped, air-space } \\
\text { occupying } \\
\text { GGOs in the } \\
\text { left lower lobe }\end{array}$ & $\begin{array}{l}11 \mathrm{~mm} \text { sized } \\
\text { GGO nodule } \\
\text { in the superior } \\
\text { segment of the } \\
\text { right lower lobe }\end{array}$ \\
\hline Treatment & Erythromycin & $\begin{array}{l}\text { Right upper } \\
\text { lobectomy }\end{array}$ & $\begin{array}{l}\text { High dose } \\
\text { prednisolone and/ } \\
\text { or azathioprine }\end{array}$ & $\begin{array}{l}\text { Surgical } \\
\text { removal under } \\
\text { the possibility } \\
\text { of malignancy }\end{array}$ & $\begin{array}{l}\text { Regular } \\
\text { follow-up, only }\end{array}$ & $\begin{array}{l}\text { Superior } \\
\text { segmentectomy } \\
\text { of the right } \\
\text { lower lobe }\end{array}$ \\
\hline Outcome & $\begin{array}{l}\text { Improvement in } \\
\text { the lung function }\end{array}$ & $\begin{array}{l}\text { Improvement in } \\
\text { symptoms }\end{array}$ & $\begin{array}{l}\text { No significant } \\
\text { improvement in } \\
\text { the lung lesions }\end{array}$ & $\begin{array}{l}\text { No new lesions } \\
\text { were found on } \\
\text { the chest CT at } \\
\text { the } 10 \text { months } \\
\text { follow-up }\end{array}$ & $\begin{array}{l}\text { Consolidation } \\
\text { in left lung } \\
\text { completely } \\
\text { disappeared } \\
\text { over } 5 \text { months }\end{array}$ & $\begin{array}{l}\text { No new findings } \\
\text { on follow up } \\
\text { image }\end{array}$ \\
\hline
\end{tabular}

CT: computed tomography, GGO: ground-glass opacities.

Therefore, pathological evaluation was needed to confirm the diagnosis. Of the two separate lesions, the hypermetabolic RLL lesion was surgically removed and submitted for histopathological diagnosis. Finally, and unexpectedly, she was diagnosed as having FB.

Most patients with FB complain of dyspnea, productive cough, hemoptysis, or chest pain. Some patients may have fever or weight loss. In cases of FB secondary to connective tissue diseases, progressively worsening dyspnea is the main symptom [3]. Although PFT is often nonspecific, PFT can reveal a restrictive, obstructive, or mixed pattern in FB patients. The changes of PFT could be mild although the abnormalities on chest radiography were severe [13]. Additionally, chest radiographic findings are often normal in FB, but may show hyperinflation, small nodules or reticular or reticulonodular infiltrates in a severe case. The most frequent findings of HRCT are small centrilobular nodules ( 1 to $3 \mathrm{~mm}$ ) associated with GGOs [14]. The patient of the present case patient did not complain of any respiratory symptoms and showed normal PFTs. Also, she showed two discrete nodules measuring over $10 \mathrm{~mm}$ in diameter on chest CT imaging. In such clinical context, before the segmentectomy, we believed that she was more likely to have a malignant lesion than a benign pathology.

Bronchiolitis is one of the most common airway diseases in SS patients and it may be isolated or associated with interstitial pneumonitis. Pathologically, different types of bronchiolitis have been described and they include FB, chronic bronchiolitis, obliterative bronchiolitis, lymphocytic bronchiolitis, constrictive bronchiolitis associated with bronchiolar destruction and panbronchiolitis [2]. Histopathologies of FB are characterized by nodular aggregates of peribronchial or peribronchiolar lymphoid cells with or without reactive germinal centers. The lesions distribute along the bronchovascular bundles with mild degrees of lymphocytic or monocytic infiltration in the interlobular septum [13]. But, in the case of FB, the alveolar septa remains largely spared. On the other hand, extensive alveolar septal involvement favors lymphocytic interstitial pneumonia (LIP). LIP shows histological features similar to those of $\mathrm{FB}$ and can also occur in patients 
with SS. In the present case, there was no extensive septal involvement of the B cell dominant lesion.

The lung involvement could contribute to an elevated risk of death in SS patients [12,15], but all pulmonary manifestations of SS do not require an active treatment [2]. In FB secondary to connective tissue diseases, the treatment is usually aimed at controlling the underlying primary disease. The course of FB associated with SS has been described as being mild and stable [2]. Glucocorticoids, rituximab, or macrolides has been prescribed for the treatment of severe cases, but these therapeutic approaches have a low level of evidence [2]. As described in Table 1, FB was spontaneously resolved in the Korean case with RA [8], but FB in the case with Castleman's disease did not respond to high doses of prednisolone and azathioprine [9]. In the present case, the GGO nodule in RLL was surgically removed and the other nodular lesion in LUL remained. While maintaining the conservative treatment, the LUL lesion was post-operatively stable for four months and no further lesion was identified. But the possibility of malignancy could not be ruled out. If the size of the LUL lesion had progressively increased in serial chest CT, the patient cannot help but repeat surgical resection. However, if the size change is minimal, glucocorticoid therapy might be considered under the likelihood of FB.

\section{SUMMARY}

Conclusively, this report is the first one about FB in a Korean patient with primary SS which mimicked lung cancer. Clinical pulmonary manifestations are various in patients with SS. FB can not be easily diagnosed, because FB is pathologically confirmed and has non-specific clinical features. Therefore, Clinicians should include FB as a differential diagnosis of nodular lesion in SS although it is a rare manifestation.

\section{CONFLICT OF INTEREST}

No potential conflict of interest relevant to this article was reported.

\section{REFERENCES}

1. Mariette X, Criswell LA. Primary Sjögren's Syndrome. N Engl J Med 2018;378:931-9.

2. Flament $T$, Bigot A, Chaigne B, Henique $H$, Diot $E$, Marchand-Adam S. Pulmonary manifestations of Sjögren's syndrome. Eur Respir Rev 2016;25:110-23.

3. Tashtoush B, Okafor NC, Ramirez JF, Smolley L. Follicular bronchiolitis: a literature review. J Clin Diagn Res 2015;9: OE01-5.

4. Pipavath SJ, Lynch DA, Cool C, Brown KK, Newell JD. Radiologic and pathologic features of bronchiolitis. AJR Am J Roentgenol 2005;185:354-63.

5. Fortoul TI, Cano-Valle F, Oliva E, Barrios R. Follicular bronchiolitis in association with connective tissue diseases. Lung 1985;163:305-14.

6. Lee YJ, Park JH, Cho GJ, Lee BC, Kim DS, Suh YL, et al. A case of follicular bronchitis/bronchiolitis. Korean J Med 1993;45:795-800.

7. Lee JH, Choi M, Oh SS, Choi MR, Yang HJ, Lee KM, et al. Case of follicular bronchiolitis in rheumatoid arthritis. J Rheum Dis 2016;23:392-5.

8. Hwangbo Y, Cha SI, Lee YH, Lee SY, Seo H, Oh S, et al. A case of multicentric castleman's disease presenting with follicular bronchiolitis. Tuberc Respir Dis (Seoul) 2013;74: 23-7.

9. Kim MS, Lim SC, Kim YH, Na KJ, Kim KS, Kwon KY, et al. A case report of localized form of follicular bronchitis/ bronchiolitis with fibrosis. Tuberc Respir Dis 1998;45: 191-6.

10. Jeong Y, Bang YH, Kim YK. Migrating persistent pulmonary consolidation in a child: a case of follicular bronchiolitis. Pediatr Pulmonol 2017;52:E22-5.

11. Ysamat Marfá R, Benito Ysamat A, Espejo Pérez S, Blanco Negredo M, Roldán Molina R. Lung disease associated with connective tissue disease. Radiologia 2013;55:107-17.

12. Kim HJ, Kim KH, Hann HJ, Han S, Kim Y, Lee SH, et al. Incidence, mortality, and causes of death in physician-diagnosed primary Sjögren's syndrome in Korea: a nationwide, population-based study. Semin Arthritis Rheum 2017;47: 222-7.

13. Aerni MR, Vassallo R, Myers JL, Lindell RM, Ryu JH. Follicular bronchiolitis in surgical lung biopsies: clinical implications in 12 patients. Respir Med 2008;102:307-12.

14. Howling SJ, Hansell DM, Wells AU, Nicholson AG, Flint JD, Müller NL. Follicular bronchiolitis: thin-section CT and histologic findings. Radiology 1999;212:637-42.

15. Palm O, Garen T, Berge Enger T, Jensen JL, Lund MB, Aaløkken TM, et al. Clinical pulmonary involvement in primary Sjogren's syndrome: prevalence, quality of life and mortality--a retrospective study based on registry data. Rheumatology (Oxford) 2013;52:173-9. 